\title{
Utilization of Lightweight Materials Made from Coal Gasification Slags
}

\section{Quarterly Report \\ June - August 1995}

September 1995

Work Performed Under Contract No.: DE-FC21-94MC30056

For

U.S. Department of Energy

Office of Fossil Energy

Morgantown Energy Technology Center

Morgantown, West Virginia

By

Praxis Engineers, Inc.

Milpitas, California

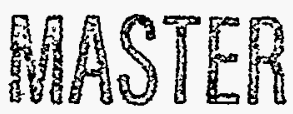

DISTREUTTION OF THIS DOCUMENT IS UNLLWHTED 


\section{DISCLAIMER}

This report was prepared as an account of work sponsored by an agency of the United States Government. Neither the United States Government nor any agency thereof, nor any of their employees, makes any warranty, express or implied, or assumes any legal liability or responsibility for the accuracy, completeness, or usefulness of any information, apparatus, product, or process disclosed, or represents that its use would not infringe privately owned rights. Reference herein to any specific commercial product, process, or service by trade name, trademark, manufacturer, or otherwise does not necessarily constitute or imply its endorsement, recommendation, or favoring by the United States Government or any agency thereof. The views and opinions of authors expressed herein do not necessarily state or reflect those of the United States Government or any agency thereof.

This report has been reproduced directly from the best available copy.

Available to DOE and DOE contractors from the Office of Scientific and Technical Information, 175 Oak Ridge Turnpike, Oak Ridge, TN 37831; prices available at (615) 576-8401.

Available to the public from the National Technical Information Service, U.S. Department of Commerce, 5285 Port Royal Road, Springfield, VA 22161; phone orders accepted at (703) 487-4650. 
㟔

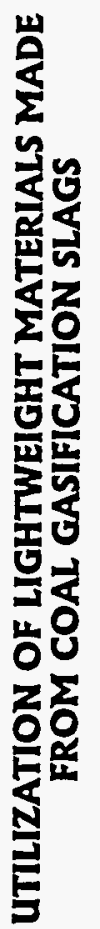

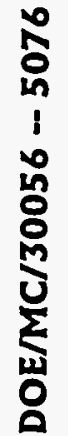




\title{
Utilization of Lightweight Materials Made from Coal Gasification Slags
}

\author{
Quarterly Report \\ June - August 1995
}

Work Performed Under Contract No.: DE-FC21-94MC30056

\author{
For \\ U.S. Department of Energy \\ Office of Fossil Energy \\ Morgantown Energy Technology Center \\ P.O. Box 880 \\ Morgantown, West Virginia 26507-0880
}

By

Praxis Engineers, Inc.

852 North Hillview Drive

Milpitas, California 95035

September 1995 


\section{TABLE OF CONTENTS}

1.0 PROJECT OBJECTIVES, SCOPE AND DESCRIPTION OF TASKS $\ldots \ldots \ldots \ldots 1$

1.2 Scope of Work $\ldots \ldots \ldots \ldots \ldots \ldots \ldots \ldots \ldots \ldots \ldots \ldots \ldots \ldots \ldots \ldots$

1.3 Task Description . . . . . . . . . . . . . . . . . . . . 2

1.4 Scope of this Document ...................... 2

2.0 SUMMARY OF WORK DONE DURING THIS REPORTING PERIOD $\ldots \ldots \ldots \ldots$

2.1 Summary of Accomplishments $\ldots \ldots \ldots \ldots \ldots \ldots \ldots \ldots \ldots, 3$

2.2 Chronological Listing of Significant Events $\ldots \ldots \ldots \ldots \ldots \ldots \ldots$

3.0 TO DATE ACCOMPLISHMENTS $\ldots \ldots \ldots \ldots \ldots \ldots \ldots \ldots \ldots$

4.0 TECHNICAL PROGRESS REPORT $\ldots \ldots \ldots \ldots \ldots \ldots \ldots \ldots \ldots \ldots \ldots \ldots$

$4.1 \quad$ Primary Slag Sample Preparation $\ldots \ldots \ldots \ldots \ldots \ldots \ldots \ldots \ldots \ldots$

$4.2 \quad$ Gasifier Feed Coal Analysis . . . . . . . . . . . . . . . . . 7

4.3 Laboratory Evaluation of Secondary Slag Sample and Clay Blends . . . . . 8

$4.3 \quad$ Economic Analysis $\ldots \ldots \ldots \ldots \ldots \ldots \ldots \ldots \ldots \ldots . \ldots \ldots$

4.4 Conclusions and Recommendations . . . . . . . . . . . . . . 11

$5.0 \quad$ PLAN FOR THE NEXT QUARTER $\ldots \ldots \ldots \ldots \ldots \ldots \ldots \ldots \ldots \ldots \ldots$ 


\subsection{PROJECT OBJECTIVES, SCOPE AND DESCRIPTION OF TASKS}

\section{$1.1 \quad$ Introduction}

Integrated-gasification combined-cycle (IGCC) technology is an emerging technology that utilizes coal for power generation and production of chemical feedstocks. However, the process generates large amounts of solid waste, consisting of vitrified ash (slag) and some unconverted carbon. In previous projects, Praxis investigated the utilization of "as-generated" slags for a wide variety of applications in road construction, cement and concrete production, agricultural applications, and as a landfill material. From these studies, we found that it would be extremely difficult for "as-generated" slag to find large-scale acceptance in the marketplace even at no cost because the materials it could replace were abundantly available at very low cost. It was further determined that the unconverted carbon, or char, in the slag is detrimental to its utilization as sand or fine aggregate. It became apparent that a more promising approach would be to develop a variety of value-added products from slag that meet specific industry requirements. This approach was made feasible by the discovery that slag undergoes expansion and forms a lightweight material when subjected to controlled heating in a kiln at temperatures between 1400 and $1700^{\circ} \mathrm{F}$. These results indicated the potential for using expanded slag as a substitute for conventional lightweight aggregates (LWA). The technology to produce lightweight and ultra-lightweight aggregates (ULWA) from slag was subsequently developed by Praxis with funding from the Electric Power Research Institute (EPRI), Illinois Clean Coal Institute (ICCl), and internal resources.

The major objectives of the subject project are to demonstrate the technical and economic viability of commercial production of LWA and ULWA from slag and to test the suitability of these aggregates for various applications. The project goals are to be accomplished in two phases, each of 15 months duration. Phase 1 , which includes the production of LWA and ULWA from slag at the large pilot-scale, is due for completion on 14 December 1995. The scheduled completion date of Phase II, which involves commercial utilization of these aggregates in a number of applications, is 14 March 1997.

Primary funding for the project was provided by DOE's Morgantown Energy Technology Center (METC) with significant cost sharing by Electric Power Research Institute (EPRI) and Illinois Clean Coal Institute (ICCI).

\subsection{Scope of Work}

The project scope consists of collecting a large sample of slag (primary slag) which will be processed for char removal and then subjected to thermal or pyroprocessing to produce expanded slag aggregates of various size gradations and unit weights, ranging from 12 to 50 $\mathrm{lb} / \mathrm{ft}^{3}$. A second slag sample will be used for confirmatory testing. Technical data generated during production and testing of the products will be used to assess the overall technical viability of expanded slag production. The expanded slag aggregates will then be tested for their suitability in manufacturing precast concrete products (e.g., masonry blocks and roof tiles) and insulating concrete, first at the laboratory scale and subsequently in commercial manufacturing plants. These products will be evaluated using ASTM and industry test methods. 
In addition, a market assessment will be made based on an evaluation of both the expanded slag aggregates and the final products, and market prices for these products will be established. In order to assess the economic viability of these utilization technologies, relevant cost data for physical and pyroprocessing of slag to produce expanded slag aggregates will be gathered for comparison with (i) the management and disposal costs for slag or similar wastes and (ii) production costs for conventional materials which the slag aggregates would replace. This will form the basis for an overall economic evaluation of expanded slag utilization technologies.

\section{$1.3 \quad$ Task Description}

A summary of the tasks to be performed in Phase $\mathrm{I}$ is given below:

Task 1.1 Laboratory and Economic Analysis Plan Development Development of a detailed work plan for Phase I and an outline of the Phase II work.

Task 1.2 Production of Lightweight Aggregates from Slag: Selection and procurement of project slag samples, slag preparation including screening and char removal, and slag expansion in direct- and indirect-fired furnaces. Preliminary laboratory-scale studies will be conducted before bulk samples of expanded slag are collected for processing. The char recovered from the slag preparation operation will be evaluated for use as a kiln fuel and gasifier feed. Environmental data will also be collected during preparation and expansion of slag.

Task 1.3 Data Analysis of Slag Preparation and Expansion: Analysis and interpretation of project data, including development of material and energy balances for slag processing and product evaluation.

Task 1.4 Economic Analysis of Expanded Slag Production: Economic analysis of the utilization of expanded slag by determining production costs for slagbased LWAs and ULWAs. An estimated market value will be established for the various expanded slag products. Expanded slag production costs will be compared with the costs of disposal and management of slag as a solid waste.

Task 1.5 Topical and Other Reports: Preparation and delivery of topical, financial status, and technical progress reports in accordance with the Statement of Work.

The Phase II effort will focus on field studies conducted on expanded slag aggregates to test their performance as substitutes for conventional materials in various applications, including masonry blocks, roof tiles, insulating concrete, and insulation fill. Mix designs will be formulated and tested by refining the material proportions used in previous work. Commercial manufacturing practices, standards, and equipment will be used for this work. New applications may also be identified during the course of this work. The economic analyses conducted in Phase I will be further refined in Phase II using the new data. 


\subsection{Scope of this Document}

This is the fourth quarterly report and summarizes the work undertaken during the performance period between 1 June 1995 and 31 August 1995.

\subsection{SUMMARY OF WORK DONE DURING THIS REPORTING PERIOD}

\subsection{Summary of Accomplishments}

The following was accomplished during the current reporting period:

1. A semi-continuous pilot-scale tabling operation was set up, shaken down, and made operational at Penn State for removal of char from slag.

2. Processing of the primary slag sample, consisting of seventy 55-gallon drums, or nearly $4200 \mathrm{lb}$, was completed at Penn State.

3. During processing of the primary slag, samples of the feed to the tabling process, char, and product slag were collected and analyzed. The size and ash analysis of the primary slag sample was then compared with that of the advance sample, as reported in Quarterly Report No. 1. It was found that the samples had similar ash contents but their particle size distributions were quite different.

4. Samples of the feed and products of the char removal process were collected to conduct mass and ash balances for the process for the primary slag sample. The data were then compared with those for the advance sample.

5. The processed slag was dried, screened at 10 mesh and 50 mesh sizes, packed in drums, and shipped to Fuller Company for kiln processing to produce lightweight aggregates.

6. Along with the slag, 5-gallon samples of the gasifier coal slurry feed and char collected from the fine slag dewatering circuit were received from the gasifier facility and characterized.

7. Laboratory testing of the secondary slag derived from an Illinois coal feed was completed at Fuller. This included testing of the coarse slag in the form of discrete particles and of the fine slag in pellet form after extrusion using an expansive clay binder.

8. Work on the economic analysis was initiated and is still in progress. 


\subsection{Chronological Listing of Significant Events}

The following significant events occurred during the current reporting period:

\begin{tabular}{||l|l||}
\hline \multicolumn{1}{|c|}{ Date } & \multicolumn{1}{c|}{ Description } \\
\hline $06 / 01 / 95$ & Pilot unit for char removal set up \\
\hline $06 / 21 / 95$ & Secondary slag sample tested and evaluated \\
\hline $06 / 30 / 95$ & Operational problems solved and continuous slag processing started \\
\hline $08 / 20 / 95$ & Processing of the primary slag sample for char removal completed \\
\hline $08 / 31 / 95$ & Slag screening at 10 mesh and 50 mesh started \\
\hline $08 / 31 / 95$ & Preliminary mass balance around the char removal process completed \\
\hline
\end{tabular}

\subsection{TO DATE ACCOMPLISHMENTS}

This section documents the work completed to date in the first three quarters of the project:

\begin{tabular}{||l|l||}
\hline \multicolumn{1}{|c|}{ Date } & \multicolumn{1}{c|}{ Accomplishments } \\
\hline $10 / 24 / 1994$ & "Draft Laboratory and Economic Analysis Plan" prepared and submitted \\
\hline $11 / 07 / 1994$ & $\begin{array}{l}\text { Advance slag sample collected from operating gasifier and sent to Penn State } \\
\text { University }\end{array}$ \\
\hline $11 / 18 / 94$ & $\begin{array}{l}\text { Tabling operation on advance sample successfully completed and prepared slag } \\
\text { sent to Fuller and Silbrico for expansion }\end{array}$ \\
\hline $12 / 02 / 94$ & Final "Laboratory and Economic Analysis Plan" prepared and submitted \\
\hline $12 / 14 / 94$ & $\begin{array}{l}\text { Testing of advance slag sample at Fuller and Silbrico indicates that it has excellent } \\
\text { expansion properties }\end{array}$ \\
\hline $02 / 15 / 94$ & Analysis of clay and slag to evaluate blending initiated at Fuller \\
\hline $03 / 05 / 95$ & Decision made regarding primary and secondary project slag samples \\
\hline $04 / 15 / 95$ & $\begin{array}{l}\text { Laboratory extrusion testing of the advance sample using an expansive clay binder } \\
\text { completed at Fuller }\end{array}$ \\
\hline $05 / 21 / 95$ & Primary slag sample received at Penn State for preparation \\
\hline $05 / 30 / 95$ & $\begin{array}{l}\text { Characterization and analysis of primary slag initiated; particle size distribution and } \\
\text { ash analysis of two drums of sample completed }\end{array}$ \\
\hline $06 / 01 / 95$ & Pilot unit for char removal set up \\
\hline $06 / 21 / 95$ & Secondary slag sample tested and evaluated \\
\hline $06 / 30 / 95$ & Operational problems solved and continuous slag processing started \\
\hline $08 / 20 / 95$ & Primary slag sample processing for char removal completed \\
\hline $08 / 31 / 95$ & Slag screening at 10 mesh and 50 mesh started \\
\hline $08 / 31 / 95$ & Preliminary mass balance around the char removal process completed \\
\hline
\end{tabular}




\subsection{TECHNICAL PROGRESS REPORT}

\subsection{Primary Slag Sample Preparation}

Processing of 70 drums (nearly $4200 \mathrm{lb}$ ) of the primary slag sample for char removal by means of a shaking table was the major accomplishment in this quarter. This sample was too large to be processed in a laboratory-scale unit and too small to warrant building a pilot plant to process it on a continuous basis. Therefore, the necessary equipment was assembled at Penn State to allow a semi-continuous slag processing circuit which could process the slag one drum at a time at steady-state conditions. The tabling operation took more time than anticipated since the equipment had to be repaired frequently; also, the high moisture content of the slag caused severe flow problems which took some time to overcome. However, the results obtained were very consistent, and comparison of analyses of the product slag samples from one drum to another indicated that variations were within acceptable limits.

4.1.1 Characterization of the Primary Sample. During the char removal process, samples were collected from the feed and product (both slag and char) streams. Characterization of the feed samples included moisture analysis (percent solids), particle size distribution, and composition (ash) analysis. The $25 \%$ feed slag moisture content posed considerable material handling problems during processing for char removal. The total ash content of the feed analyzed at $85.6 \%$, which was close to the $86.1 \%$ ash level determined for the 5-gallon advance sample tested in the first quarter of the project. Measurement of the particle size distribution allows determination of the amount of material that will need to be pelletized (typically, minus 50-mesh fines are expanded following pelletization). Table 1 presents a comparison of the particle size distribution of the as-received primary slag sample with that of the advance sample, as reported in Quarterly Report No. 1.

Table 1. Size Distribution Analysis of Primary Slag vs. Advance Sample

\begin{tabular}{||l|c|c|l|l|l||}
\hline \multicolumn{3}{|c|}{ Primary Slag Sample } & \multicolumn{3}{c||}{ Advance Slag Sample } \\
\hline \hline Size & $\begin{array}{c}\text { Direct } \\
\text { Wt } \%\end{array}$ & $\begin{array}{c}\text { Cumulative } \\
\text { Wt\% }\end{array}$ & \multicolumn{1}{|c|}{ Size } & $\begin{array}{c}\text { Direct } \\
\text { Wt\% }\end{array}$ & $\begin{array}{c}\text { Cumulative } \\
\text { Wt\% }\end{array}$ \\
\hline \hline$+6 \mathrm{M}$ & 4.3 & 4.3 & $+6 \mathrm{M}$ & 11.1 & 11.1 \\
\hline $6 \times 8 \mathrm{M}$ & 7.3 & 11.6 & $6 \times 8 \mathrm{M}$ & 20.4 & 31.5 \\
\hline $8 \times 12 \mathrm{M}$ & 21.5 & 33.1 & $8 \times 10 \mathrm{M}$ & 22.2 & 53.7 \\
\hline $12 \times 16 \mathrm{M}$ & 11.9 & 44.9 & $10 \times 14 \mathrm{M}$ & 16.1 & 69.7 \\
\hline $16 \times 20 \mathrm{M}$ & 7.0 & 51.9 & $14 \times 20 \mathrm{M}$ & 9.2 & 79.0 \\
\hline $20 \times 28 \mathrm{M}$ & 5.5 & 57.4 & $20 \times 28 \mathrm{M}$ & 4.7 & 83.7 \\
\hline $28 \times 35 \mathrm{M}$ & 5.6 & 62.9 & $28 \times 35 \mathrm{M}$ & 2.3 & 85.9 \\
\hline $35 \times 48 \mathrm{M}$ & 10.1 & 73.0 & $35 \times 48 \mathrm{M}$ & 4.1 & 90.0 \\
\hline $48 \times 65 \mathrm{M}$ & 8.7 & 81.6 & $48 \times 65 \mathrm{M}$ & 3.0 & 93.0 \\
\hline $65 \times 100 \mathrm{M}$ & 7.0 & 88.6 & $-65 \mathrm{M}$ & 7.0 & 100.0 \\
\hline$-100 \mathrm{M}$ & 11.5 & 100.0 & & & \\
\hline Total & 100.0 & & Total & 100.0 & \\
\hline
\end{tabular}


As may be seen in the table, the primary slag sample contains a larger proportion of fines than the advance sample; for example, the minus $48 \mathrm{M}$ fraction constituted $27 \%$ of the primary sample as against only $10 \%$ of the advance sample. This larger quantity of fines also contributed to handling problems during char removal. The results from processing the primary slag sample would be considered as the basis for design of a commercial system.

4.1.2 Pilot Plant Operation. The slag-char separation was done using a shaking table. Since slurry transfer from the drums was difficult, the feed to the table was provided manually. The char-free slag was collected in 5-gallon buckets and transferred to clean drums. The rejects (char) stream was collected in a sump and later pumped into drums. The slag and char were periodically dewatered by decantation. The slag was then dried in small batches in an oven overnight. Since this was a semi-continuous process, it took longer than the scheduled time.

The mass balance around the char removal system, based on $100 \mathrm{lb}$ of raw slag feed, is presented in Table 2. Slag samples were collected during processing of the primary slag sample. Analyses of two test runs (i.e., tests 31 and 32), which represent typical operational data with respect to the ash content of the feed, char, and slag streams, are presented in this table. The table shows that slag products consisting of $100 \%$ ash were recovered at yields of 66 to $68 \%$. Also, a char product containing 45 to $54 \%$ ash was recovered during the process. This char product will be evaluated as a potential feed material to the gasifier to utilize the fuel value associated with its carbon content.

Table 2. Mass Balance Around Char Removal System

\begin{tabular}{|c|c|c|c|c|c|c|c|c|c|c|c|}
\hline \multirow[b]{3}{*}{$\begin{array}{l}\text { Test } \\
\text { No. }\end{array}$} & & & \multirow{2}{*}{\multicolumn{2}{|c|}{$\begin{array}{c}\text { Screening } \\
+6 \mathrm{M} \text { Slag } \\
\text { Product }\end{array}$}} & \multicolumn{6}{|c|}{ Tabling } & \multirow{3}{*}{$\begin{array}{c}\text { Product } \\
\text { Yield } \\
\%\end{array}$} \\
\hline & \multicolumn{2}{|c|}{ Raw Slag } & & & \multicolumn{2}{|c|}{ Feed Slag } & \multicolumn{2}{|c|}{ Char } & \multicolumn{2}{|c|}{ Product Slag } & \\
\hline & $\begin{array}{l}\text { Wt } \\
\text { lb }\end{array}$ & $\begin{array}{c}\text { Ash, } \\
\%\end{array}$ & $\begin{array}{l}\text { Wt } \\
\text { lb }\end{array}$ & $\begin{array}{c}\text { Ash, } \\
\%\end{array}$ & $\begin{array}{l}\text { Wt } \\
\text { lb }\end{array}$ & $\begin{array}{c}\text { Ash, } \\
\%\end{array}$ & $\begin{array}{l}\text { Wt } \\
\text { lb }\end{array}$ & $\begin{array}{c}\text { Ash, } \\
\%\end{array}$ & $\begin{array}{l}\text { Wt } \\
\text { lb }\end{array}$ & $\begin{array}{c}\text { Ash, } \\
\%\end{array}$ & \\
\hline 31 & 100 & 83.5 & 0.0 & 0.0 & 100.0 & 83.5 & 31.7 & 46.9 & 68.3 & 100.5 & 68.3 \\
\hline 32 & 100 & 84.9 & 0.0 & 0.0 & 100.0 & 84.9 & 34.3 & 54.6 & 65.7 & 100.7 & 65.7 \\
\hline AS-1* & 100.0 & 86.1 & 11.1 & 100.2 & 88.9 & 74.7 & 25.7 & 45.1 & 63.2 & 100.2 & 74.3 \\
\hline
\end{tabular}

*Advance slag sample, reported in Quarterly Report No. 1.

Table 2 also shows the results obtained from processing of the advance slag sample for char removal. In the case of this sample, the coarse fraction ( +6 mesh) was separated before processing for char removal and recovered as $100 \%$ ash material. Table 2 presents the results from processing of the minus 6-mesh fraction of the advance slag sample in comparison with those for the entire primary slag sample. As can be seen from the table, the grade/recoveries from the tabling operation for the two samples are quite similar. However, the total product yield of the advance sample was higher because it contained a larger proportion of material $(11.1 \%$ by weight) in the $+6 \mathrm{M}$ fraction than did the primary sample ( $4.3 \%$ by weight) and the advance sample was processed in smaller batches with better process control.

The results obtained from char removal processing of the primary slag were consistent, as illustrated in Table 3, which shows the particle size analysis and ash content of each size fraction of the two product slag samples collected for this purpose. 
Table 3. Product Slag Sample Analysis

\begin{tabular}{||c|c|c|c|c||}
\hline & \multicolumn{2}{|c|}{ Test 31 } & \multicolumn{2}{c||}{ Test 32 } \\
\hline Size, US Mesh & Wt, \% & Ash, \% & Wt, \% & Ash, \% \\
\hline+6 & 7.4 & 101.4 & 7.6 & 101.0 \\
\hline $6 \times 12$ & 32.8 & 100.9 & 38.8 & 100.7 \\
\hline $12 \times 16$ & 16.4 & 101.2 & 19.0 & 101.0 \\
\hline $16 \times 30$ & 19.0 & 100.9 & 18.1 & 100.9 \\
\hline $30 \times 50$ & 9.1 & 98.0 & 6.7 & 99.9 \\
\hline $50 \times 70$ & 4.9 & 97.8 & 3.1 & 99.6 \\
\hline $70 \times 100$ & 3.6 & 99.3 & 2.3 & 99.9 \\
\hline-100 & 6.8 & 100.5 & 4.4 & 100.9 \\
\hline Total & 100.0 & 100.5 & 100.0 & 100.7 \\
\hline
\end{tabular}

\subsection{Gasifier Feed Coal Analysis}

Along with the primary slag sample, 5-gallon samples of the gasifier coal slurry feed and char collected from the fine slag dewatering circuit were received from the gasifier facility and characterized. Table 4 presents the analysis of the coal feed to the gasifier.

Table 4. Gasifier Feed Coal Analysis

\begin{tabular}{||l|c|c|c||}
\hline \multicolumn{1}{|c|}{ Sieve Size } & Weight\% & Ash, \% & Sulfur, \% \\
\hline$+1^{\prime \prime}$ & 8.6 & 13.4 & 2.93 \\
\hline $1 \times 3 / 4^{\prime \prime}$ & 10.4 & 11.5 & 3.00 \\
\hline $3 / 4^{\prime \prime} \times 1 / 2^{\prime \prime}$ & 14.6 & 9.7 & 3.03 \\
\hline $1 / 2^{\prime \prime} \times 3 / 8^{\prime \prime}$ & 13.4 & 8.5 & 2.80 \\
\hline $3 / 8^{\prime \prime} \times 1 / 4^{\prime \prime}$ & 17.4 & 8.5 & 2.87 \\
\hline $1 / 4^{\prime \prime} \times 4 \mathrm{M}$ & 11.0 & 8.4 & 2.78 \\
\hline $4 \times 6 \mathrm{M}$ & 7.5 & 8.6 & 2.81 \\
\hline $6 \times 12 \mathrm{M}$ & 4.1 & 8.4 & 2.73 \\
\hline $12 \times 16 \mathrm{M}$ & 0.7 & 8.5 & 2.75 \\
\hline $16 \times 30 \mathrm{M}$ & 1.9 & 8.6 & 2.63 \\
\hline $30 \times 50 \mathrm{M}$ & 2.2 & 9.6 & 2.83 \\
\hline $50 \times 70 \mathrm{M}$ & 1.2 & 11.9 & 2.94 \\
\hline $70 \times 100 \mathrm{M}$ & 1.5 & 14.9 & 3.12 \\
\hline$-100 \mathrm{M}$ & 5.4 & 22.8 & 3.58 \\
\hline Total & 100.0 & 10.3 & 2.92 \\
\hline Head & & 10.1 & 2.83 \\
\hline \hline
\end{tabular}




\subsection{Laboratory Evaluation of Secondary Slag Sample and Clay Blends}

In this quarter, laboratory expansion of the secondary slag sample generated from an Illinois coal feed was completed to evaluate the following issues related to commercial utilization of slag:

- The feasibility of producing coarse aggregates from coarse slag $(+10 \mathrm{M})$

- The feasibility of producing coarse aggregates from slag fines

The potential for blending slag fines with an expansible clay.

For the latter two items, as with the test work conducted in the previous quarter, an expansive clay was selected for use as a binder since it can participate in the expansion process and is abundantly available at low cost. Expansive clay also offers good binding capability and expansion characteristics, and expands in a temperature range close to slag $\left(\sim 2000^{\circ} \mathrm{F}\right)$. Based on the successful results obtained in the previous quarter, the same clay was used for the secondary slag sample. The current laboratory-scale work included testing the coarse slag in discrete particle form and the fine slag in pellet form after extrusion using an expansive clay binder. Table 5 presents the results obtained from expansion work conducted at Fuller on both the coarse and fine slag samples.

Table 5. Laboratory Expansion of Secondary Slag

\begin{tabular}{|c|c|c|c|c|c|c|}
\hline $\begin{array}{l}\text { Test } \\
\text { No. }\end{array}$ & Size & $\begin{array}{l}\text { Slag/Clay } \\
\text { Wt Ratio }\end{array}$ & $\begin{array}{l}\text { Extrusion } \\
\text { Moisture, \% }\end{array}$ & $\begin{array}{l}\text { Expansion } \\
\text { Temp., }{ }^{\circ} \mathrm{F}\end{array}$ & $\begin{array}{l}\text { Feed Unit } \\
\mathrm{Wt},\left(\mathrm{lb} / \mathrm{ft}^{3}\right)\end{array}$ & $\begin{array}{c}\text { Product Visual } \\
\text { Eval/Unit Wt }\left(\mathrm{lb} / \mathrm{ft}^{3}\right)\end{array}$ \\
\hline \multirow[t]{3}{*}{1} & +10 Mesh & $100: 0$ & NA & 1400 & 80.5 & 43.0 \\
\hline & & & $\overline{N A}$ & 1450 & & 28.4 \\
\hline & & & NA & 1500 & & 19.7 \\
\hline \multirow[t]{3}{*}{2} & -50 Mesh & $50: 50$ & 17.3 & 1800 & NA & No expansion \\
\hline & & & & 1900 & & Good expansion \\
\hline & & & & 2000 & & Overexpansion \\
\hline \multirow[t]{3}{*}{3} & -50 Mesh & $60: 40$ & 15.87 & 1800 & NA & No expansion \\
\hline & & & & 1900 & & Moderate expansion \\
\hline & & & & 2000 & & Overexpansion \\
\hline \multirow[t]{3}{*}{4.} & -50 Mesh & $70: 30$ & 15.47 & 1800 & NA & No expansion \\
\hline & & & & 1900 & & Moderate expansion \\
\hline & & & & 2000 & & Overexpansion \\
\hline \multirow[t]{3}{*}{5.} & -50 Mesh & $80: 20$ & 11.54 & 1800 & NA & No expansion \\
\hline & & & & 1900 & & Moderate expansion \\
\hline & & & & 2000 & & Overexpansion \\
\hline $6^{*}$ & -50 Mesh & $50: 50$ & & 1900 & 58.42 & 26.9 \\
\hline 7. & -100 Mesh & $80: 20$ & 13.39 & 1900 & 60.63 & 32.6 \\
\hline
\end{tabular}

Test No. 6 was based on the qualitative results of Test No. 2 
These results confirmed the following for the +10 mesh slag:

- The +10 mesh slag could be expanded to $20-30 \mathrm{lb} / \mathrm{ft}^{3}$ at $1450-1500^{\circ} \mathrm{F}$ with a final product topsize of approximately $1 / 4 "$.

- The expansion temperature is lower than that required for thermal expansion of clays and shales $\left(2000^{\circ} \mathrm{F}\right)$.

- At temperatures above $1500^{\circ} \mathrm{F}$, the coarse slag (+10 mesh) became sticky and agglomerated.

The minus 50-mesh and minus 100-mesh slag were pelletized and expanded separately after combining with $20-50 \%$, by weight, expansive clay as a binder. These laboratory tests were successful and indicate the following:

- Minus 50-mesh slag combined with expansive clay in a 50:50 ratio by weight and extruded to form pellets produced a $+3 / 8^{\prime \prime}$ size aggregate with a unit weight of $27 \mathrm{lb} / \mathrm{ft}^{3}$ and a volume expansion of 1.7 to 1 at $1900^{\circ} \mathrm{F}$.

- Minus 100-mesh slag combined with expansive clay in an 80:20 ratio by weight and extruded to form pellets produced $a+3 / 8$ " size aggregate with a unit weight of $33 \mathrm{lb} / \mathrm{ft}^{3}$ and a volume expansion of 1.4 to 1 at $1900^{\circ} \mathrm{F}$.

- The expansion temperature of the slag fines was nearly $200^{\circ} \mathrm{F}$ lower than that of pellets made from $100 \%$ conventional expansible clay, which require expansion temperatures of $\sim 2000^{\circ} \mathrm{F}$. This represents a considerable energy savings for slag expansion. The aggregate size can be controlled during extrusion and the product unit weight can be controlled as a function of temperature.

The results of this test work are illustrated in Figure 1, which consists of photographs that show the expanded products from pyroprocessing of the +10 -mesh slag and the minus 50 - and minus 100-mesh pelletized slag/clay blends.

\subsection{Economic Analysis}

Work on economic analysis of lightweight aggregate production from gasifier slag was initiated. Preliminary cost-related data on the equipment required for char removal, the kiln and associated equipment, and slag and product storage and handling equipment were procured from Fuller. $A$ worksheet was designed to compute capital and operating costs for the entire slag-LWA manufacturing process, taking into consideration the avoided costs of disposal of the gasifier slag as waste. 
Figure 1. Expanded Slag Products from Second Slag Sample

\section{(GASIFIER SLAG RECOVERY SYSTEM PRODUCTS )}

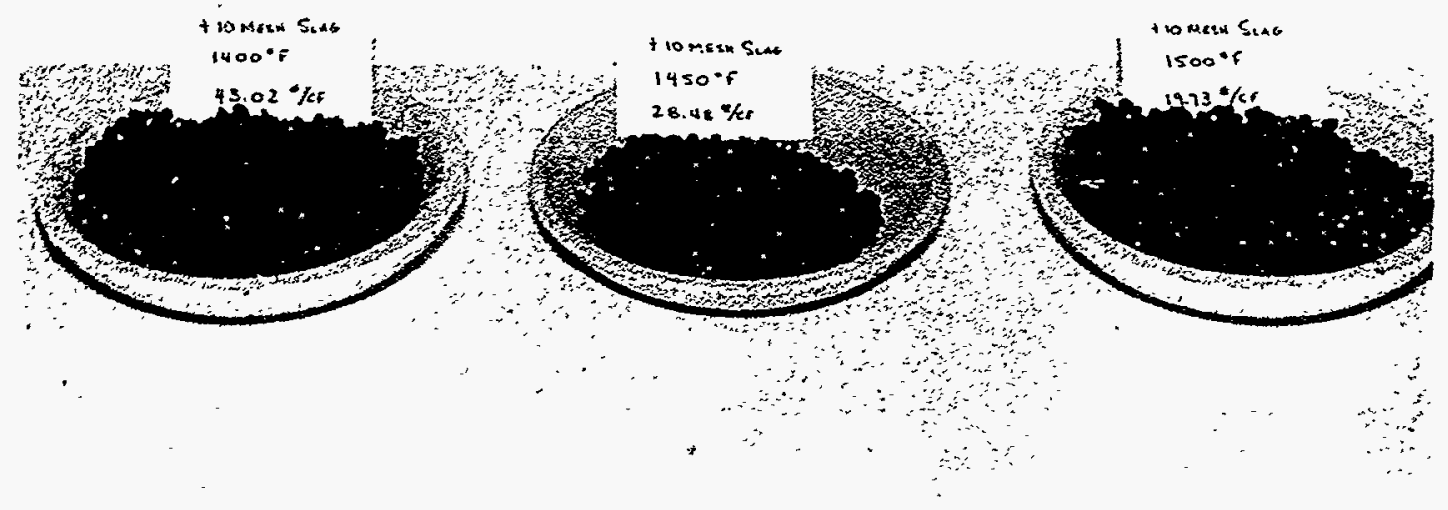

Expanded +10 Mesh Slag

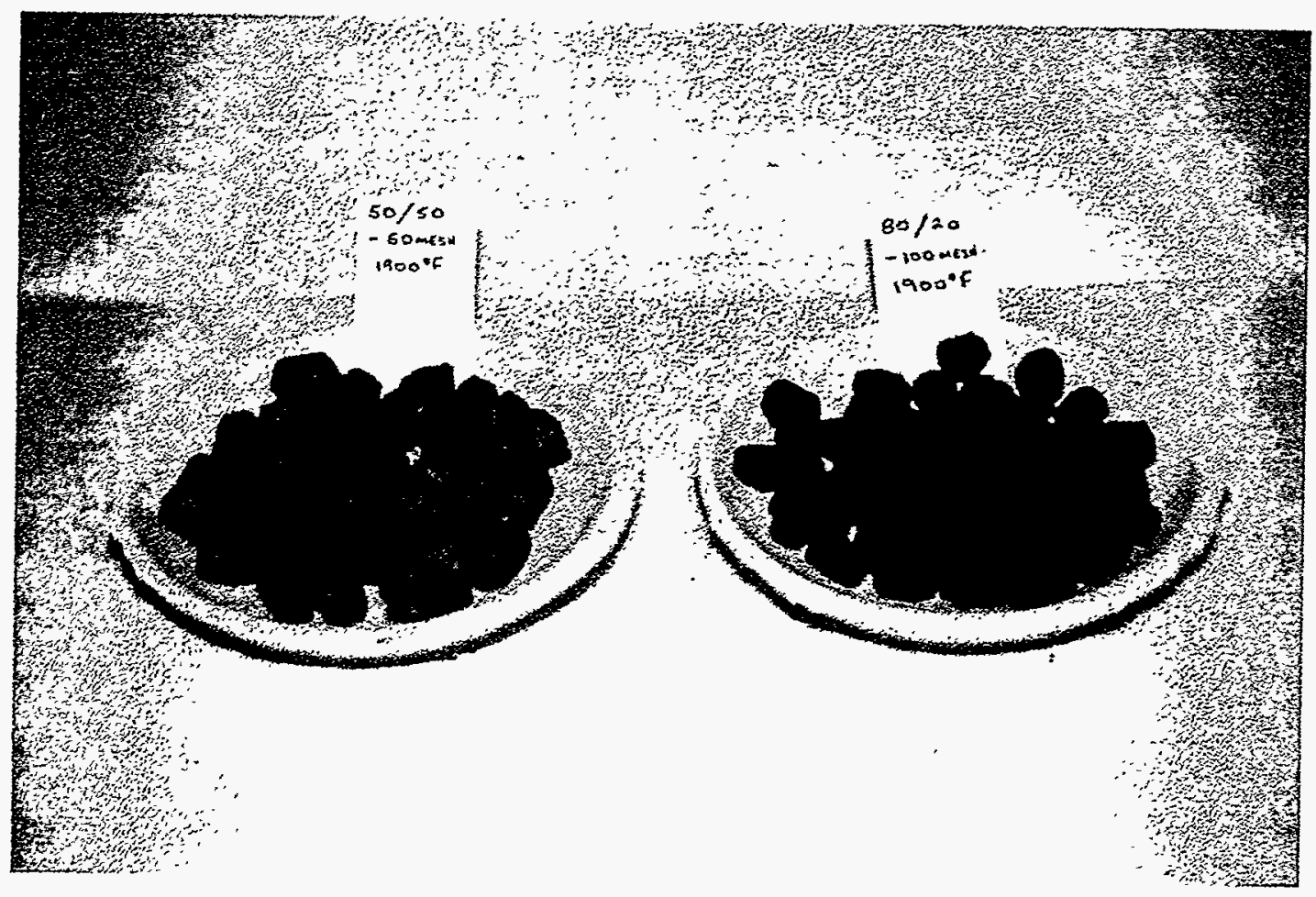

Briquetted slag/Clay Expanded Extrusions 


\subsection{Conclusions and Recommendations}

Based on the reported results, the following conclusions and recommendations can be made:

- The primary slag sample was processed for char removal at Penn State University and sent to Fuller for kiln processing. Slag containing $100 \%$ ash was recovered at yields ranging between 66 and $68 \%$. A char product containing $45-54 \%$ ash was also recovered and will be evaluated as a potential gasifier feed.

- For the second slag sample, the +10 mesh slag expanded to a unit weight of $20-30 \mathrm{lb} / \mathrm{ft}^{3}$ at 1450 to $1500^{\circ} \mathrm{F}$. This expansion temperature is $400-500^{\circ} \mathrm{F}$ lower than that typically required for expansible clays and shales.

- Size enlargement of extruded pellets made from minus 50-mesh and minus 100 -mesh fractions of the secondary slag sample using $20-50 \%$ by weight expansive clay binder was successfully conducted. The resulting aggregates had a size of 3/8" and unit weights ranging between 27 and 33 $\mathrm{lb} / \mathrm{ft}^{3}$. The expansion temperature for these samples was nearly $200^{\circ} \mathrm{F}$ lower than that typically required for conventional expansible clay pellets, which represents considerable energy savings for slag expansion. The aggregate size can be controlled during extrusion and the product unit weight can be controlled as a function of temperature. Successful expansion of pelletized slag/clay blends in a 50:50 ratio indicates that these two materials can also be blended to produce lightweight aggregates.

\subsection{PLAN FOR THE NEXT QUARTER}

The following activities are planned for the next quarter:

- Kiln processing of primary slag sample to produce lightweight aggregates

- Analysis of the operational data to establish mass and material balance for slag processing

- Work on economic analysis will continue. 